\title{
Maryla Zając
}

\section{Od elektronicznej muzyki do elektronicznego obrazu. Exposition of Music - Electronic Television Nam June Paika}

\author{
Nie uważałem się za artystę wizualnego. \\ Wiedziałem natomiast, że coś trzeba zrobić z telewizją, \\ a ponieważ nikt inny się tym nie zajmował, \\ dlaczego nie miałem to być ja? ${ }^{1}$
}

Pierwsze telewizory, które pojawiły się na rynku w latach 20. $\mathrm{xx}$ wieku, kosztowały „prawie tyle, co niewielki samochód”2. Czterdzieści lat później firma Sony rozpoczęła produkcję i dystrybucję przenośnych kamer Portapak, których stosunkowo niska cena czyniła je dostępnymi dla przedstawicieli klasy średniej³ ${ }^{3}$ Rozwój mediów maso-

1 Cyt za: L. Movin, Mistrz zen sztuki wideo. Nam June Paik: między minimalizmem a przesada, [w:] Nam June Paik. Driving media, red. A. Kubicka-Dzieduszycka, K. Dobrowolski, Wrocław 2009, s. 65.

2 [b.a.] Arirang Special(Ep.312) Nam June Paik's Art and Revolution $1_{-}$Full Episode [video], [online] https://www.youtube.com/watch?v=woE2v_rbY7s [dostęp: 23.06.2016].

3 K. Rachubińska, Fluxfilm. Między definicjami, [w:] Grupa ETC, Narracje, estetyki, geografie. Fluxus w trzech aktach, red. A. Michnik, K. Rachubińska, Warszawa 2014, s. 174. 
wych, dających możliwość rejestrowania wydarzeń, był ogromnym krokiem naprzód w rozwoju współczesnej cywilizacji. Telewizja zaczynała odgrywać coraz większą rolę w domu każdej średniozamożnej rodziny. Niezależnie od swoich oczywistych funkcji, odbiorniki telewizyjne stały się także istotnym elementem w sztukach wizualnych, szczególnie w działalności artystycznej koreańskiego artysty, Nam June Paika (1932-2006). Uważany za ojca wideo artu, po raz pierwszy zaprezentował publiczności efekt swoich eksperymentów z nową technologią w marcu 1963 roku podczas Exposition of Music - Electronic Television, dziesięciodniowej wystawy w Galerie Parnass w Wuppertalu. Stworzony przez niego environment stał się nie tylko przyczynkiem do twórczego wykorzystania możliwości telewizji, inspirującym kolejne pokolenia artystów - było to również wydarzenie, podczas którego Paik w sposób symboliczny zakończył swoje eksperymenty z action music, zwracając się w kierunku sztuk wizualnych ${ }^{5}$. W niniejszej pracy przedstawię ową wystawę, która miała miejsce w galerii Rolfa Jährlinga między 11 a 20 marca 1963 roku. Najpierw zarysuję kontekst jej powstania, odwołując się do faktów z życia Nam June Paika i jego pozycji jako artysty na początku drugiej połowy ubiegłego stulecia. Wskażę źródła inspiracji i najistotniejszych mentorów twórcy, nakreślę jego związki z działalnością artystów Fluxusu. Następnie opiszę interaktywne środowisko Exposition of Music - Electronic Television, po czym zaznaczę jej rolę w rozwoju sztuk wizualnych i dalszej karierze Paika.

\section{Przed pierwszą indywidualną ekspozycją}

Nam June Paik ${ }^{6}$ urodził się w 1932 roku w Seulu. Kilka lat później jego rodzina przeniosła się do Tokio. Nam June rozpoczął na tamtejszym uniwersytecie studia w zakresie muzyki, sztuki i filozofii,

4 S.-K. Lee, Videa 'n' Videology. Open Communication, [w:] Nam June Paik, red. S.-K. Lee, S. Rennert, London 2010, s. 27; [b.a.] Nam June Paik, «Exposition of Music - Electronic Television», 1963. Leaflet Printed for the Show, [online] http://www.medienkunstnetz. de/works/exposition-of-music [dostęp: 23.06.2016].

5 S. von Wiese, 'Your MARTYR of July 20, 1964'. Paik and Beuys in a Media Duet, [w:] Nam June Paik, red. S.-K. Lee, S. Rennert, dz. cyt., s. 128.

6 Por.: S. Fricke, Paik, Nam June, [w:] The New Grove Dictionary of Music and Musicians, red. S. Sadie, t. 18 (Nisard to Palestrina), London 1980, s. 900-901; Z. Skowron, Paik, 
mimo iż jego ojciec chciał, by syn został biznesmenem 7 . W 1956 roku w celu poszerzania wiedzy przeniósł się do Niemiec, gdzie prężnie rozwijała się interesująca go sztuka awangardowa. Rozpoczął studia w Monachium, jednak już w 1957 roku przeniósł się do Staatliche Hochschule für Musik Freiburg, gdzie podjął studia kompozycji. Podczas jednego z koncertów, na którym wykonane zostały Variations No. 1 Johna Cage’a, Koreańczyk zafascynował się kolażem dźwiękowym i preparacją fortepianu ${ }^{8}$. Kilkakrotnie brał także udział w Internationale Ferienkurse für Neue Musik w Darmstadcie, gdzie w 1958 roku poznał twórcę Wariacji, z którym połączyła go długoletnia przyjaźń i który stał się jednym z jego głównych mentorów ${ }^{9}$. Właśnie w skierowanym do Cage’a liście (datowanym na 1959 rok) Paik wspomniał o swoim zainteresowaniu wykorzystaniem telewizji w sztuce ${ }^{10}$. W 1958 roku, dzięki pomocy swojego profesora Wolfganga Fortnera, przeniósł się do Kolonii, by tam podejmować próby elektronicznego przetwarzania dźwięku w prężnie działającym studio przy Westdeutscher Rundfunk; tam też poznał Mauricia Kagela, György Ligetiego oraz Karlheinza Stockhausena. Ideologia tego ostatniego najsilniej wpłynęła na myślenie Paika w owym czasie ${ }^{11}$. Ponieważ Koreańczyk obracał się w kręgu osób zainteresowanych muzyką elektroniczną, na kształtowanie się jego upodobań twórczych wpływ miały eksperymenty Pierre’a Schaeffe$\mathrm{ra}^{12}$. Pod koniec 1961 roku zainteresowanie Paika action music osłabło; artysta nie zrezygnował jednak z eksperymentowania z elektroniką, przeciwnie - skierował swe zainteresowania ku możliwościom oferowanym przez telewizję i wideo:

Nam June, [w:] Encyklopedia Muzyczna PWM. Część biograficzna, red. E. Dziębowska, t. $7(\mathrm{~N}-\mathrm{Pa})$, Kraków 2002, s. 271-272.

7 [b.a.] Arirang Special(Ep.312)..., dz. cyt.

8 S. Fricke, Nam June Paik, Schönberg... und Cage, „Positionen. Beiträge zur neuen Musik" 39 (1999), s. 43-45; L. Movin, dz. cyt., s. 59.

9 D. Zerbib, Paik, Heidegger and the Chelsea Girl; or, Electronic Ecstasy Unveiled, [w:] Nam June Paik, red. S.-K. Lee, S. Rennert, dz. cyt., s. 200.

10 [b.a] Nam June Paik. An Illustrated Chronology, [w:] Nam June Paik, red. J.G. Hanhardt, New York 1982, s. 13.

11 L. Movin, dz. cyt., s. 57.

12 G. Föllmer, Audio Art, [online] http://www.medienkunstnetz.de/themes/overview_ of_media_art/audio/scroll/ [dostęp: 24.06.2016]. 
Spakowałem całą swoją bibliotekę i zamknąłem wszystko na klucz w komórce, pozostawiając tylko wydawnictwa dotyczące techniki telewizyjnej. Czytałem i praktykowałem wyłącznie to, co związane z elektroniką. Innymi słowy, wróciłem do spartańskich czasów sprzed studiów - tylko fizyka i elektronika ${ }^{13}$.

$\mathrm{Na}$ początku lat 6o. Paik związał się z twórcami grupy Fluxus, uczestnicząc $\mathrm{w}$ jednym $\mathrm{z}$ ich pierwszych publicznych występów, Kleines Sommerfest - Après John Cage (09.06.1962), zorganizowanym przez prowadzącego galerię w Wuppertalu Rolfa Jährlinga ${ }^{14}$. Od tego czasu Paik stał się obok George’a Maciunasa centralną postacią Fluxusu, współorganizatorem i współreżyserem spektakli ${ }^{15}$. Podczas wydarzenia NEO-DADA in der Musik (16.06.1962, Düsseldorf) otrzymał od Josepha Beuysa propozycję zorganizowania własnego koncertu w tamtejszej Kunstakademie. Paik z propozycji nie skorzystał, przede wszystkim dlatego, iż był zajęty przygotowaniami do wystawy Exposition of Music - Electronic Television. Jednak, wziąwszy pod uwagę założenia Fluxusu o oderwaniu dzieła od osobowości konkretnego twórcy oraz potrzebie tworzenia interakcji między ludźmi w dziełach kreowanych przez kolektyw, Paik zaproponował organizację wystawy różnych artystów związanych z ruchem, co ostatecznie doprowadziło do przygotowania dwudniowego Festum Fluxorum Fluxus (02-03.02.1963, Kunstakademie w Düsseldorfie) ${ }^{16}$, na którym obecny był także Jährling ${ }^{17}$. Było to ostatnie wydarzenie Fluxusu z udziałem Paika przed jego samodzielną wystawą w Wuppertalu.

13 L. Movin, dz. cyt., s. 64. Wszystkie tłumaczenia cytatów pochodzą od autorki.

14 S. Rennert, Nam June Paik. Kalendarium (1958-1968), [w:] Nam June Paik. Driving media, dz. cyt., s. 35 .

15 S. Rennert, On sunny days, count the waves of the Rhine. Wczesne lata Nam June Paika w Nadrenii (1958-1963), [w:] Nam June Paik. Driving media, dz. cyt., s. 22.

16 S. von Wiese, dz. cyt., s. 128; S. Rennert, Nam June Paik. Kalendarium..., dz. cyt., s. 35-36; S. Rennert, 'We have time'. Music, Fluxus, Video. Paik's Time in Dusseldorf, in the Rhineland, [w:] Nam June Paik, red. S.-K. Lee, S. Rennert, dz. cyt., s. 61-62.

17 Tamże, s. 59. 


\section{Exposition of Music - Electronic Television'18}

W 1961 roku Nam June Paik napisał Symphony for 20 Rooms, inspirując się poglądami Cage’a na temat muzyki stale otaczającej ludzi, jego koncepcją indeterminizmu oraz dźwięku obecnego w przedmiotach ${ }^{19}$. W założeniu artysty było to właściwie środowisko multisensoryczne, gdzie $\mathrm{w}$ każdym $\mathrm{z}$ dwudziestu pokoi miało miejsce inne zdarzenie dźwiękowe i to odbiorca decydował, w jakiej kolejności oraz czego słucha, a właściwie - w których zdarzeniach uczestniczy. I choć nie udało mu się dokładnie zrealizować pomysłu, postanowił wykorzystać go w zmodyfikowanej formie ${ }^{20}$ podczas swojej pierwszej indywidualnej wystawy zatytułowanej Exposition of Music - Electronic Television. Wydarzenie miało miejsce w Galerie Parnass w Wuppertalu, do której został zaproszony przez jej właściciela, kilkakrotnie wspominanego już Rolfa Jährlinga ${ }^{21}$. W połowie ubiegłego wieku było to jedno $\mathrm{z}$ najsilniej zaangażowanych w rozwój sztuki awangardowej miejsc w Niemczech, dających eksperymentującym artystom - zapraszanym głównie z Francji, Stanów Zjednoczonych i RFN - przestrzeń wystawienniczą i stwarzających okazję do wielogodzinnych dyskusji22. Jest właściwie pewne, że Paik nie pisał Symphony for 20 Rooms z myślą o wykonaniu $\mathrm{w}$ tej galerii; dwupiętrowy dom $\mathrm{z}$ ogrodem stał się jej siedzibą dopiero w grudniu 1961 roku $^{23}$. Początkowo wystawa miała obejmować jedynie parter budynku, jednak wraz z rozbudowywaniem się wizji Koreańczyka kolejne obiekty dźwiękowe zostały wystawiane także na piętrach, w piwnicy i w ogrodzie; ekspozycja rozszerzyła się nawet na prywatną część budynku, którą zamieszkiwało małżeństwo Jährlingów ${ }^{24}$. Wystawa trwała dziesięć dni, od 11 do 20 marca 1963 roku, i była otwarta dla publiczności wyłącznie w godzinach od 19.30 do $21.30^{25}$. Wśród

18 Fotografie instalacji dostępne są w: [b.a.] Exposition of Music-Electronic Television. Galerie Parnass, Wuppertal, 1963, [w:] Nam June Paik, red. S.-K. Lee, S. Rennert, dz. cyt., s. 96-105.

19 A. Michnik, Fluxus a pasieka, [w:] Narracje, estetyki..., dz. cyt., s. 116.

20 S. Neuburger, 'For a Philosophical Reason'. Nam June Paik and the Text, [w:] Nam June Paik, red. S.-K. Lee, S. Rennert, dz. cyt., s. 88.

21 G. Berghaus, Avant-garde Performance, London 2005.

22 [b.a.] Arirang Special(Ep.312)..., dz. cyt.

23 S. Neuburger, dz. cyt., s. 90.

24 [b.a.] Nam June Paik, «Exposition of Music - Electronic Television»..., dz. cyt.

25 Tamże. 
osób zaangażowanych w jej organizację znaleźli się: Manfred Montwé (wykonane przez niego zdjęcia są jedynym wizualnym zapisem wydarzenia), Peter Brötzmann, Thomas Schmitt oraz Frank Trowbridge. Dodatkowo pomagali Günther Schmitz i M. Zenzen ${ }^{26}$. Na wystawie wykorzystane zostały instalacje zaprezentowane przez Paika podczas innych okazji, ponadto miały miejsce premiery nowych obiektów. Wszystkie instalacje Paik stworzył z przedmiotów codziennego użytku, jednak sposób ich wykorzystania i połączenia oraz wprowadzenie do sytuacji artystycznej odbiorcy, który był zachęcany do samodzielnej interakcji z nimi, nadawało im nowy status ${ }^{27}$.

Istotna w koncepcji Paika była strona marketingowa wydarzenia. Już same przygotowane przez niego plakaty oraz ulotki nawiązywały do idei całej wystawy oraz założeń Fluxusu: wykorzystania w sztuce przedmiotów codziennego użytku oraz tworzenia kreatywnej kontry wobec snobizmu i komercjalizacji ${ }^{28}$. Plakat ${ }^{29}$, który zapowiadał wystawę, był zarazem rodzajem kolażu; Paik sprowadził mianowicie z Korei tamtejszą gazetę codzienną, „Kyunghyang”, na której czerwonym tuszem samodzielnie wydrukował techniką sitodruku informacje o wydarzeniu ${ }^{30}$. Wprowadzenie elementu wschodniej kultury podczas wystawy na zachodzie było już pierwszym sygnałem zwiastującym chęć integracji odmiennych środowisk $^{31}$. Gra z odbiorcą i tekstem widoczna była również na innym plakacie promującym wystawę, gdzie jej tytuł zapisany został w nietradycyjny sposób: EXPosition of music - ELectronic television. Wielkie litery tworzą słowo EXPEL (ang. wydalać, usuwać), istotne jest także samo słowo ex-position - nazwa wystawy miała sugerować odejście od stanu kontemplacji, odrzucenie postawy biernego odbiorcy, zmianę jego roli („pozycji”) $\mathrm{w}$ tworzeniu sztuki i jej percepcji32.

Pierwszym obiektem, z którym mieli styczność uczestnicy wydarzenia, była zawieszona nad frontowymi drzwiami świeżo odcięta głowa wołu. Miało to stanowić nawiązanie do szamańskiego rytuału, który matka Paika odprawiała co roku w październiku ${ }^{33}$. Podczas obrzędu

26 Tamże.

27 G. Föllmer, dz. cyt.

28 S. Rennert, On sunny days..., dz. cyt., s. 28.

29 [b.a.] Exposition of Music - Electronic Television..., dz. cyt., s. 97.

30 [b.a.] Arirang Special(Ep.312)..., dz. cyt.

31 Tamże.

32 D. Zerbib, dz. cyt., s. 185.

33 S. Rennert, On sunny days..., dz. cyt. s. 29. 
zwanego daegnam nol yi (lub gut ${ }^{34}$ ) tańczące kobiety, znajdujące się pod wpływem narkotyków, „wskrzeszały ducha władcy lądu przez reprezentację śmierci”"35, którą była właśnie głowa wołu. W przypadku wystawy Paika celem rytuału było symboliczne zgromadzenie różnych ludzi i bogów odmiennych religii, by mogli wspólnie brać w niej udział, ciesząc się swoją obecnością ${ }^{36}$. Jak twierdził Paik,

[...] kiedy ludzie przychodzą na mój koncert, oglądać moje obiekty, muszą zostać przeniesieni w inny stan świadomości. Muszą być na haju. Aby osiągnąć taki stan, potrzebny jest mały szok. I w ten sposób wykorzystałem ten wizualny szok. Szło się na moją wystawę, widziało się tę głowę i było się high ${ }^{37}$.

Jak wspomina Brötzmann ${ }^{38}$, Paik był zachwycony efektem, w przeciwieństwie do sąsiadów Galerie Parnass: „[głowa wołu - przyp. M.Z.] była najbardziej problematycznym ze wszystkich eksponatów. Zaczęła śmierdzieć, muchy latały wokół niej”39. Ostatecznie została usunięta po trzech dniach, po skardze sąsiadów i policyjnej interwencji ${ }^{0}$. $\mathrm{Ci}$ z uczestników, którzy zdecydowali się wejść do galerii, trafiali w environment angażujący wszystkie zmysły. Od drugiego piętra po piwnicę i ogród rozciągały się różne instalacje autorstwa Paika, które miały stanowić nawiązanie do Symphony for 20 Rooms. W pierwszym pomieszczeniu, do którego trafiała publiczność, stały cztery fortepiany, z czego trzy były preparowane - wśród nich znajdował się Klavier Intégral ${ }^{41}$. I choć widać tutaj nawiązanie do koncepcji preparowania instrumentów zaproponowanej przez Johna Cage’a (co Paik podkreślił w broszurze rozdawanej podczas wydarzenia, która zawierała - obok informacji

34 Y. Lee, Nam June Paik as a Thought-Diver, [w:] Nam June Paik, red. S.-K. Lee, S. Rennert, dz. cyt., s. 173-174.

35 Tamże, s. 174 .

36 Tamże.

37 S. Rennert, On sunny days..., dz. cyt., s. 29.

38 [b.a.] Arirang Special(Ep.312)..., dz. cyt.

39 Tamże.

40 Tamże.

41 [b.a.] Nam June Paik, "Exposition of Music - Electronic Television»..., dz. cyt.; D. Ronte, Nam June Paik's Early Works in Vienna, [w:] Nam June Paik, red. J.G. Hanhardt, New York 1982, s. 74; G. Berghaus, dz. cyt., b.p.; J. Anderson $\mathrm{i}$ in., The Fine Art of Success. How Learning Great Art Can Create Great Business, Hoboken 2011, b.p. 
o wystawie - istotne teksty autorstwa jego i Jean-Pierre'a Wilhelma ${ }^{42}$, to podejścia artystów się różniły. W przypadku Amerykanina chodziło o tymczasową zmianę: urozmaicenie barwy dźwięku, wzbogacenie walorów brzmieniowych pianina, które może zaraz po wykonaniu utworu powrócić do swojej pierwotnej postaci. Z kolei Koreańczyk świadomie dążył do nieodwracalnej destrukcji instrumentu, do zmiany jego onto$\operatorname{logii}{ }^{43}$. Dodatkowo celem Paika była tytułowa integracja różnorodnych zmysłów - nie tylko słuchu i dotyku - podczas interakcji z pianinem ${ }^{44}$. Wspomniany już Klavier Intégral nawiązywał w budowie i wyglądzie do pianina, jednak Paik, poprzez wbudowanie różnorodnych mechanizmów do jego wnętrza oraz przyczepienie do niego (czy też zintegrowanie z nim) innych obiektów, stworzył całkowicie nową jakość. Artysta ozdobił i urozmaicił wygląd pianina kablami, drutem kolczastym, lalkami, biustonoszem czy jajkami ${ }^{45}$. Poszczególne klawisze były przerobione na przyciski wywołujące określone zdarzenia: włączały radio, wiatrak, lampę ${ }^{46}$. Inne pianino zostało przez Paika przewrócone, dając tym samym publiczności możliwość grania na jego klawiszach stopami $^{47}$. Z kolei klawisze w Piano K były sklejone, co uniemożliwiało grę na instrumencie ${ }^{48}$. Jednak największe zaciekawienie wzbudziło pianino niepoddane (przynajmniej przez Paika) preparacji ${ }^{49}$. Otóż w trakcie ceremonii otwierającej wystawę przyjaciel twórcy, Joseph Beuys, podbiegł do obiektu i zaczął okładać go młotem ${ }^{50}$. Montwé wspomina to wydarzenie w następujący sposób:

Przyglądałem się ceremonii otwierającej, stojąc na piętrze. Mężczyzna o nazwisku Joseph Beuys chwycił siekierę. Właściwie to był olbrzymi młot. Chwycił go

42 D. Daniels, John Cage and Nam June Paik. 'Change your mind or change your receiver (your receiver is your mind)', [w:] Nam June Paik, red. S.-K. Lee, S. Rennert, dz. cyt., s. 116; S. Rennert, Nam June Paik. Kalendarium..., dz. cyt., s. 37.

43 D. Daniels, John Cage and Nam June Paik..., dz. cyt., s. 115.

44 [b.a.] Arirang Special(Ep.312)..., dz. cyt.

45 J. Anderson i in., dz. cyt., b.p.

46 G. Berghaus, dz. cyt., b.p.

47 Tamże, b.p.

48 Por. S. Muchnic, Shozo Shimamoto, [online] http://articles.latimes.com/1998/feb/o1/ entertainment/ca-14275/2 [dostęp: 25.05.2016]; S. Rennert, Nam June Paik..., s. 39.

49 [b.a.] Arirang Special(Ep.312)...; J. Anderson i in., dz. cyt.; S. von Wiese, dz. cyt., s. 129; S. Rennert, On sunny days..., dz. cyt., s. 29-30.

50 Źródła nie są zgodne, czy był to młot czy siekiera, por. [b.a.] Nam June Paik: 1932..., dz. cyt., s. 12; [b.a.] Arirang Special(Ep.312)..., dz. cyt.; S. von Wiese, dz. cyt., s. 129. 
i uderzył nim w pianino. [...] Sądziliśmy, że powinniśmy go jakoś powstrzymać, więc zacząłem oblewać go wodą ${ }^{51}$.

Beuys nie powiedział otwarcie, dlaczego zdecydował się na takie działanie. Podczas jednych z prowadzonych przez siebie zajęć przyznał jednak, że destrukcja stanowi konieczne i uzasadnione działanie: „Destrukcja i konstrukcja są nierozdzielnie połączone wszędzie tam, gdzie ludzie mają ze sobą do czynienia. Aby stworzyć coś nowego trzeba zniszczyć to, co stare" ${ }^{32}$. Prawdopodobnie był to także rodzaj hołdu złożonego Paikowi, gdyż artysta widział, jak Koreańczyk roztrzaskał skrzypce wykonując One for Violin Solo podczas NEO-DADA in der $M u s i k^{53}$. Im San, profesor na wydziale zarządzania sztuką Uniwersytetu Dongguk, także przychyla się do takiej interpretacji działań Beuysa:

\footnotetext{
W tamtych czasach wielu artystów kopiowało dzieła ulubionych twórców w celu złożenia im hołdu. W Zachodnich Niemczech rosło znaczenie Nam June Paika, a on i Joseph Beuys wiedzieli o sobie nawzajem. Dlatego poprzez powtórne odtworzenie aktu zniszczenia pianina, którego już dokonał Nam June Paik, sądzę, że chciał mu złożyć hołd ${ }^{54}$.
}

Artysta musiał szybko zrozumieć intencję Beuysa, gdyż - jak zanotował Schmitt - powiedział później: „Podobało mi się"55.

Innym ważnym obiektem zaprezentowanym podczas Exposition of Music - Electrical Television była interaktywna instalacja złożona z dwunastu używanych telewizorów (trzynasty zepsuł się podczas transportu, pokazując po włączeniu jedynie białą, pionową linię; Paik nazwał go Zen for TV i również wykorzystał podczas wystawy) ${ }^{56}$. Nie wszystkie telewizory były tradycyjnie postawione; niektóre leżały na swoich bokach i ,plecach", przez co zmieniała się percepcja obrazu, który Paik dodatkowo przekształcił, ingerując w jego horyzontalne i wertykalne aspekty ${ }^{57}$. Telewizory wykorzystane zostały jako elementy różnych obiektów ${ }^{58}$ : w Participation TV dźwięk mówiony do mikrofonu przekształcany był

51 [b.a.] Arirang Special(Ep.312)..., dz. cyt.

52 S. Rennert, On sunny days..., dz. cyt., s. 30; S. von Wiese, dz. cyt., s. 129.

53 S. Rennert, On sunny days..., dz. cyt., s. 29.

54 [b.a.] Arirang Special(Ep.312)..., dz. cyt.

55 S. Rennert, On sunny days..., dz. cyt., s. 30.

56 D. Zerbib, dz. cyt., s. 185.

57 Tamże; J. Anderson i in., dz. cyt.

58 Por. G. Berghaus, dz. cyt. 
w obrazy pojawiające się na ekranie; Kuba $T V$ polegał na połączeniu telewizora z magnetofonem - obraz zmieniał się wraz ze zmieniającym się sygnałem; Points of Light działało na podobnej zasadzie jak Kuba $T V$, jednak w tym wypadku obrazem sterowało się za pomocą gałki głośności radia. Instalacja Rembrandt Automatic złożona była ze starego telewizora odwróconego ekranem do podłogi; miało to być nawiązanie do postaci Rembrandta, który manipulował światłocieniem w przedstawieniach swojej postaci na płótnach. Podobnie było w tym przypadku: ekran wyświetlał różne obrazy, niewidoczne jednak dla odbiorcy ${ }^{59}$. Najprawdopodobniej właśnie z powodu owych telewizyjnych instalacji godziny otwarcia wystawy były tak nietypowe; w połowie XX wieku w Niemczech nadawał tylko jeden kanał telewizyjny, w dodatku wyłącznie od 18.00 do $22.30^{60}$.

Eksperymenty Paika z odbiornikami telewizyjnymi były zaskoczeniem nawet dla najbliższych mu osób - nikomu nie powiedział, że wynajął specjalne atelier do tych celów ${ }^{61}$. Jak pisał twórca w tekście podsumowującym wystawę, zatytułowanym Afterlude to the Exposition of Experimental Television:

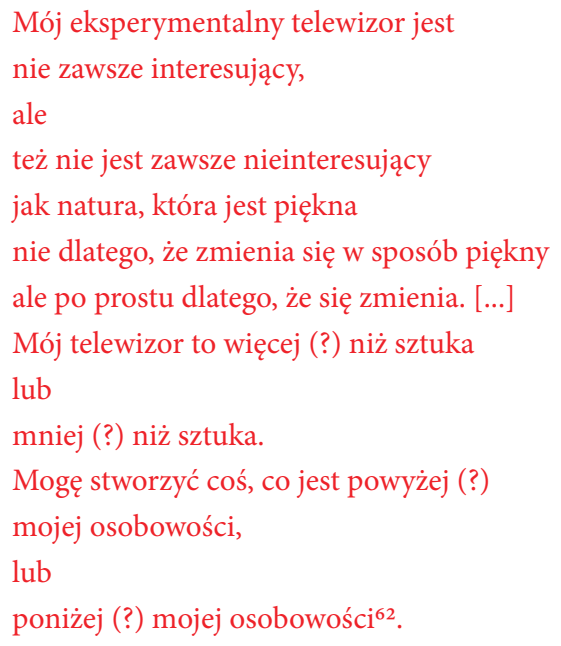

59 L. Landy, Technik, Amsterdam 1992, s. 83.

60 [b.a.] Arirang Special(Ep.312)..., dz. cyt.

61 Tamże.

62 Cyt. za: S.-K. Lee, dz. cyt., s. 28-29; N.J. Paik, «AFTERLUDE to the Exposition of EXPERIMENTAL TELEVISION», [online] http://www.medienkunstnetz.de/sourcetext/31 [dostęp: 25.06.2016]. 
$\mathrm{Z}$ jednej strony owa wypowiedź wiąże się z ideą indeterminizmu, $\mathrm{z}$ drugiej z koncepcją Fluxusu dotyczącą tworzenia obiektów będących poza ich tradycyjnym, snobistycznym kontekstem, za to skierowanych ku zwykłym ludziom i przedmiotom na co dzień przez nich wykorzystywanym. To także potwierdzenie, iż wytwory artystów Fluxusu powinny być pojmowane w oderwaniu od osobowości ich twórców. Warto wspomnieć, że dla odwiedzających wystawę telewizyjna instalacja nie była interesująca; większość osób jedynie zerkała do pokoju, w którym została umieszczona, nie przywiązując większej wagi do obiektów dających początek sztuce wideo ${ }^{63}$.

Na wystawie Paik przedstawił także inne instalacje swojego autorstwa. Schallplatten-Schaschlik, umieszczony w piwnicy, tworzyły "nadziane” na cienki kij i obracające się symultanicznie płyty gramofonowe - to publiczność, dotykając igłą konkretnej płyty, decydowała, która będzie "grać"64. W Listening to Music Through the Mouth, aby wydobyć dźwięk z gramofonu, należało wziąć do ust część w kształcie męskiego członka i nakierować doczepioną do niej igłę na płytę ${ }^{65}$. Zen for Walking tworzyły przywiązane do struny skrzypce, które można było ciągnąć za sobą, wydobywając $z$ instrumentu nietypowe dźwięki i zmieniając tym samym jego funkcję $e^{66}$. W Random Access fragmenty taśm magnetofonowych wisiały na ścianie, zachęcając odbiorców/wykonawców do tworzenia własnej muzyki przez pocieranie ich $\mathrm{w}$ dowolnym tempie głowicą magnetyczną, połączoną z odtwarzaczem magnetofonowym ${ }^{67}$. W ogrodzie zamontowano Zen for Wind; Paik powiesił na sznurkach różnorodne obiekty, w tym klucz, lalkę, puszkę i drewniane gałki, które obijały się o siebie, bądź publiczność uderzała w nie kijem golfowym ${ }^{68}$. Erinnerung an das 20. Jahrhundert tworzyły zdjęcia i artykuły prasowe nawiązujące do śmierci Marilyn Monroe ${ }^{69}$, Box of Zen było otwartą walizką wypełnioną różnymi przedmiotami: gazetami, kablami, przedmiotami osobistymi ${ }^{70}$, a Urmusik tworzyła skrzynia towarowa przekształcona w instrument ${ }^{71}$.

63 [b.a.] Nam June Paik, «Exposition of Music - Electronic Television»..., dz. cyt.

64 [b.a.] Arirang Special(Ep.312)..., dz. cyt.; G. Föllmer, dz. cyt.

65 G. Berghaus, dz. cyt., b.p.

66 Tamże, b.p.

67 L. Landy, dz. cyt., s. 86; G. Berghaus, dz. cyt., b.p.

68 S. Rennert, On sunny days..., dz. cyt., s. 29; G. Berghaus, dz. cyt., b.p.

69 Tamże, s. 29.

70 [b.a.] Exposition of Music - Electronic Television..., s. 101.

71 S. Rennert, Nam June Paik..., s. 39. 
W łazience na piętrze Galerie Parnass, w wypełnionej wodą wannie leżał zepsuty manekin sklepowy (Bathroom with Mannequin in Bath$t u b$ ), znad którego Paik w białej masce ogłosił koniec dotychczasowej sztuki - była to zarazem krytyka zachodniej cywilizacji konsumpcyjnej, uznającej swoje wytwory za najbardziej wartościowe ${ }^{72}$. W kuchni wystawione zostały obiekty autorstwa innych twórców Fluxusu, m.in. Alison Knowles ${ }^{73}$. Jednak ta różnorodność obiektów nie przyciągnęła szczególnej uwagi ani „Zwykłych” odbiorców (ponoć na otwarciu obecni byli prawie wyłącznie przyjaciele, a w pozostałych dniach pojawiło się niewiele osób ${ }^{74}$ ), ani krytyków, którzy poświęcili się opisowi pierwszego, „Zwierzęcego” eksponatu, właściwie pomijając resztę wystawy ${ }^{75}$.

\section{Fluxus i Paik}

Słowo „fluxus” oznacza - między innymi - ciągłą zmienność, przetwarzalność, transformację. W swoim manifeście George Maciunas uwypuklił także jego znaczenie w terminologii chemicznej, gdzie odnosi się ono do zespalania metali. Artyści związani z ruchem chcieli „łączyć kadry kulturowych, społecznych i politycznych rewolucji we wspólny front działania"76. Wychodząc od idei sztuki pomiędzy mediami artyzmu i ży$\mathrm{cia}^{77}$, inspirując się ready mades Marcela Duchampa, zachęcali odbiorców do spostrzeżenia w swoich dziełach nie banalnych przedmiotów, lecz obiektów sztuki, od wieków postrzeganej jako sacrum, które koegzystowały z profanum codziennego życia ${ }^{78}$. Artyści przenieśli swoją uwagę z wytworów na narzędzia wytwarzania i odtwarzania, zadając fundamentalne pytanie o naturę przedmiotów, przez które przemawiała sztuka epok wcześniejszych, ale też czasów współczesnych ${ }^{79}$. Sztuka nowocze-

72 [b.a.] Arirang Special(Ep.312)...

73 Por.: A. Michnik, dz. cyt., s. 116; S. Rennert, Nam June Paik..., s. 37.

74 D. Daniels, Telewizja - sztuka czy antysztuka?, [w:] Nam June Paik. Driving media, dz. cyt., s. 87 .

75 [b.a.] Arirang Special(Ep.312)..., dz. cyt.

76 G. Maciunas, Fluxus Manifesto, Düsseldorf 1963.

77 Por. G. Dziamski, Od syntezy sztuk do sztuki post-medialnej, „Estetyka i Krytyka” 2009, $\mathrm{nr} 2$-2010, nr 1, s. 35; R. Rothman, Fluxus, or the Work of Art in the Age of Information, „symplokë” 23 (2015), nr 1-2, s. 313.

78 G. Dziamski, dz. cyt., s. 35.

79 S. Shaw-Miller, Visible Deeds of Music. Art and Music form Wagner to Cage, New Haven 2002, s. 209. 
sna miała łączyć różne poziomy - wizualny, brzmieniowy, tekstowy w jedno, choć za podstawę owej hybrydy uważano muzykę. Stanowiła ona przestrzeń dla "gry” między wszystkimi gałęziami - gry zarówno w znaczeniu wykonania utworu muzycznego, jak i teatralnej sztuki oraz interakcji tekstów, obiektów ${ }^{80}$. Fluxus wywodzi się od muzyki, dźwięku, tak jak go interpretował John Cage (Maciunas był jego uczniem), przez który artyści eksplorowali grunt pomiędzy mediami, „obiektami”, kategoriami narzuconymi przez akademię ${ }^{81}$. Dodatkowo, jak komentuje działania twórców Fluxusu Simon Shaw-Miller, „zachodnia kultura muzyczna ukształtowała rytuały wykonawcze tak, by odizolować tekst od kontekstu i by zminimalizować przypadkowość w warstwie wizualnej i brzmieniowej. Zminimalizowano też ekspresję fizyczną do tej, której wymaga wydobycie dźwięku"82. Wielowarstwowy performance przedstawicieli Fluxusu miał zaznaczyć rolę ciała, gestu, krótko mówiąc - warstwy wizualnej (będącej nieodłącznym elementem muzyki ${ }^{83}$ ) oraz człowieka w dziejącej się sztuce. To był jeden z powodów włączenia publiczności w akt tworzenia dzieł, które w ten sposób oddziaływały na jej członków, zachęcały do postrzegania najbliższej im rzeczywistości w nowy sposób, ale też były podstawą tworzenia społecznych więzi na linii artysta-obiekt-odbiorcy ${ }^{84}$. Człowiek stał się elementem środowiska $\mathrm{z}$ jednej strony artystycznego, z drugiej znanego mu z codziennego życia, postrzegając inaczej nie tylko przedmioty, ale także siebie - nie jako biernego odbiorcę, lecz twórcę, od którego zależy ich istnienie. W myśl idei Duchampa, sztuka „nie jest wykonywana tylko przez artystę”; to właśnie „widzowie przenoszą dzieło poza rzeczywistość" ${ }^{85}$. Dzięki ich obecności możliwa jest realizacja kolejnego postulatu Fluxusu, dotyczącego przypadkowości w sztuce ${ }^{86}$. Odbiorcy wpływają na ostateczny kształt dzieła, wynoszą je poza jego przedmiotowość poprzez swoje doświadczenia, temperamenty, codzienne przyzwyczajenia ${ }^{87}$. Wytwory sztuki przestały być postrzegane jako obiekty idealne; położono nacisk - wzorując się na

\footnotetext{
8o Tamże, s. 209, 233.

81 Tamże, s. 211.

82 Tamże, s. 233.

83 Tamże, s. 212.

84 R. Rothman, dz. cyt., s. 316.

85 S. Shaw-Miller, dz. cyt., s. 225.

86 Tamże, s. 224-225.

87 Tamże, s. 222.
} 
kluczowej dla przedstawicieli Fluxusu estetyce Cage’a - na komunikację i interaktywnośćs 8 .

Od czasu odczytu Sztuka i technika - nowa jedność, wygłoszonego przez Waltera Gropiusa w 1923 roku, artyści awangardowi zaczęli kierować uwagę ku technologii, która z jednej strony pozwalała na przeprowadzanie nowych eksperymentów w obrębie sztuki, umożliwiała wprowadzanie zmian niejako w czasie rzeczywistym, $\mathrm{z}$ drugiej - na ich utrwalenie dla przyszłych pokoleńn ${ }^{89}$. W przestrzeni publicznej i prywatnej pojawiało się coraz więcej kamer, urządzeń świetlnych i dźwiękowych ${ }^{90}$; a im bardziej powszechny stawał się elektroniczny obraz, tym większe było zainteresowanie Fluxusu filmem i wideo. O roli nagrań świadczy też fakt, iż w latach 60. XX wieku ,informacja była energią, procesem i siłą, które miały być rozprzestrzeniane wśród ludzi poprzez wideo" ${ }^{11}$. Artyści widzieli w nim wiele korzyści: wykorzystanie go wiązało się z postulatem eksploracji medium tworzącego sztukę, ale też pozwalało w nowy sposób zobaczyć i zespolić rzeźbę, malarstwo, słowo oraz muzykę z człowiekiem, redefiniując Wagnerowski Gesamtkunstwerk ${ }^{92}$.

Powyższe idee znalazły odzwierciedlenie w Exposition of Music Electronic Television. Wyrażała to intermedialna makro- i mikrostruktura wystawy: zestawienie różnorodnych mediów oraz łączenie różnych obiektów i sztuk w ramach poszczególnych dzieł. Kluczowa była także rola publiczności, bez której dzieła nie mogłyby istnieć. Nie tylko wchodziła ona z nimi w interakcję; dawała możliwość wprowadzania wieloznaczności, przypadkowości, także na poziomie współistnienia różnych brzmień i obrazów „dziejących się” w danej chwili. Paik otworzył świat „wysokiej” sztuki oraz nowoczesnej technologii dla ludzi niezainteresowanych dotąd tymi zagadnieniami, zachęcając - w myśl postulatów Fluxusu - do gry, komunikacji i interakcji z nią.

88 G. Dziamski, dz. cyt., s. 37; S. Shaw-Miller, dz. cyt., s. 242.

89 G. Dziamski, dz. cyt., s. 35.

90 Tamże, s. 36; J. G. Hanhardt, Video Art. Expanded Forms, „Leonardo” 23 (1990), nr 4, s. 439.

91 P. Mellencamp, The Old and the New. Nam June Paik, „Art Journal” 54 (1995), nr 4, S. 41.

92 Ch. Mehring, Television Art's Abstract Starts. Europe circa 1944-1969, „October” 2008, t. 125, s. 30-35; J.G. Hanhardt, Nam June Paik (1932-2006). Video Art Pioneer, „American Art” 20 (2006), nr 2, s. 153; C.L. Carter, Aesthetics, Video Art and Television, „Leonardo” 12 (1979), nr 4, s. 292; J. G. Hanhardt, Video Art..., dz. cyt., s. 437. 
Jest kilka powodów wyboru właśnie instrumentów muzycznych i odbiornika telewizyjnego jako centralnych mediów przekazu. Z jednej strony w latach 6o. XX wieku oba walczyły o pierwszeństwo w salonie: fortepian coraz wyraźniej postrzegany był w kategoriach przeszłości, ustępując miejsca telewizji ${ }^{93}$. Dodatkowo zarówno instrumenty, które twórca zmodyfikował, jak i wynalazki technologiczne, wymagają znajomości i wprawy w użytkowaniu. Warto też zwrócić uwagę na fakt, iż unowocześnienie instrumentów zbliżyło je do wytworów technologii. Nie można zapomnieć, że Paik zajmował się tworzeniem elektronicznej (a więc nowoczesnej, „technologicznej”) muzyki podczas pobytu w Kolonii. Spojrzał także ponad granicami wideo i muzyki, znajdując ich wspólną cechę: zarówno światło, jak i dźwięk rozprzestrzeniają się za pomocą fal; różnica między nimi tkwi w odmiennej częstotliwości ${ }^{94}$. Dla twórcy obraz i dźwięk były związane; sam potwierdzał zainteresowanie działaniami Karla Ottona Götza z pogranicza malarstwa i technologii ${ }^{95}$. Widział w jego wytworach kinestetyczne obrazy, dzieła wizualne poddające się manipulacji, wchodzące w dyskurs z człowiekiem. Nowe, abstrakcyjne „obrazy” Paika nie były już jednorazowe, można było je zmieniać, „naprawiac" ${ }^{96} \mathrm{w}$ ich nowych ramach - telewizorach. Zróżnicowane „defekty” nadawały im indywidualny rys, a nastawianie na interakcję zbliżyło do człowieka, zarówno jako instrumenty, jak i dzieła sztuki i techniki.

Przekraczanie granic podczas Exposition of Music - Electronic Television odbywało się na wielu poziomach: $\mathrm{w}$ jednym budynku, podczas jednej wystawy ludzie z różnych środowisk obcowali z obiektami reprezentującymi to, co przeszłe i przyszłe; zachodnia tradycja koegzystowała $\mathrm{z}$ azjatycką symboliką; powaga mieszała się z żartem; obraz,

93 „Pianino i telewizor - dla kulturalnego niemieckiego obywatela około 1960 roku nie mogło być większego kontrastu: pianino jako obiekt akcjonistyczny zostało w najprawdziwszym znaczeniu tego słowa przekształcone w korpus dźwiękowy, a telewizor został po raz pierwszy poważnie potraktowany jako część naszego świata. [...] W tej samej chwili telewizja stała się po raz pierwszy częścią kulturowego dyskursu, Paik rozpoznał moment przemiany struktury władzy, następującej dzięki partycypacji - istotnemu tematowi sztuki mediów", zob. W. Herzogenrath, Wschodnio-zachodni nomada w zaciszu globalnej sieci, [w:] Nam June Paik. Driving media, dz. cyt., s. 46.

94 I. Blom, The Touch through Time. Raoul Hausmann, Nam June Paik and the Transmission Technologies of the Avant-Garde, „Leonardo” 34 (2001), nr 3, s. 213.

95 Ch. Mehring, dz. cyt., s. 30, 45.

96 Tamże, s. 45. 
dźwięk, technologia, eksperyment i człowiek wymagały swojej obecności. Kluczowa stała się refleksja nad przemijaniem i trwaniem ${ }^{97}$. Podstawą doświadczania sztuki, manipulowania jej obiektami był czas - dlatego też pojawiło się pytanie o sposób datowania dzieła: czy jest nim moment stworzenia koncepcji, obiektu, czy może pierwszy kontakt z człowiekiem? Jak komentuje Ina Blom,

Główne pytanie o czas stworzenia może być powiązane $\mathrm{z}$ faktem, iż pytanie o „kiedy” czy czasowość w dziełach Paika zostało podjęte przez niego samego na początku lat 6o. XX wieku. To właśnie zainteresowanie owym „kiedy” było powodem, dla którego Paik przeniósł się od elektronicznej muzyki ku obrazowi telewizyjnemu ${ }^{98}$.

1 kwietnia 1963, wraz z pojawieniem się kanału ZDF, niemieccy telewidzowie zyskali możliwość wyboru między dwiema stacjami99. Telewizja zaczęla nabierać znaczenia nie tylko w sztuce, ale też w życiu codziennym.

\section{Bibliografia}

[b.a.] Arirang Special(Ep.312) Nam June Paik's Art and Revolution 1 _ Full Episode [video], [online] https://www.youtube.com/watch?v=woE2v_rbY7s [dostęp: 23.06.2016].

[b.a.] Nam June Paik, «Exposition of Music - Electronic Television», 1963. Leaflet printed for the show, [online] http://www.medienkunstnetz.de/works/exposition-of-music [dostęp: 23.06.2016].

Anderson J. i in., The Fine Art of Success. How Learning Great Art Can Create Great Business, Hoboken 2011.

Berghaus G., Avant-garde Performance, London 2005.

Blom I., The Touch through Time. Raoul Hausmann, Nam June Paik and the Transmission Technologies of the Avant-Garde, „Leonardo” 34 (2001), nr 3 .

Carter C.L., Aesthetics, Video Art and Television, „Leonardo” 12 (1979), $\mathrm{nr} 4$.

Föllmer G., Audio Art, [online] http://www.medienkunstnetz.de/themes/overview_of_media_art/audio/scroll [dostęp: 24.06.2016].

97 I. Blom, dz. cyt., s. 213.

98 Tamże, s. 214.

99 D. Daniels, Telewizja - sztuka..., dz. cyt., s. 89. 
Fricke S., Nam June Paik, Schönberg... und Cage, „Positionen. Beiträge zur neuen Musik" Bd. 39 (1999).

Fricke S., Paik, Nam June, [w:] The New Grove Dictionary of Music and Musicians, red. S. Sadie, t. 18 (Nisard to Palestrina), London 1980.

Grupa ETC, Narracje, estetyki, geografie. Fluxus w trzech aktach, red. A. Michnik, K. Rachubińska, Warszawa 2014.

Hanhardt J. G., Video Art. Expanded Forms, „Leonardo” 23 (1990), nr 4.

Landy L., Technik, Amsterdam 1992.

Maciunas G., Fluxus Manifesto, Düsseldorf 1963.

Mellencamp P., The Old and the New. Nam June Paik, „Art Journal" 54 (1995), $\mathrm{nr} 4$.

Muchnic S., Shozo Shimamoto, [online] http://articles.latimes. com/1998/feb/o1/ entertainment/ca-14275/2 [dostęp: 25.05.2016].

Nam June Paik, red. J.G. Hanhardt, New York 1982.

Nam June Paik, red. S.-K. Lee, S. Rennert, London 2010.

Nam June Paik. Driving media, red. A. Kubicka-Dzieduszycka, K. Dobrowolski, Wrocław 2010.

Paik N.J., "AFTERLUDE to the Exposition of EXPERIMENTAL TELEVISION», [online] http://www.medienkunstnetz.de/source-text/31 [dostęp: 25.06.2016].

Rothman R., Fluxus, or the Work of Art in the Age of Information, „symplokë" 23 (2015), $\mathrm{nr}$ 1-2.

Skowron Z., Paik, Nam June, [w:] Encyklopedia Muzyczna PWM. Część biograficzna, red. E. Dziębowska, t. 7 (N-Pa), Kraków 2002.

\section{Abstract}

From electronic music to electronic image. Nam June Paiks Exposition of Music - Electronic Television

Nam June Paik (1932-2006) is now considered to be the most influential creator in visual arts. He is said to be the first artist who presented television as a source of artistic experience. However, nowadays many people forget about his musical beginnings. Starting as a musician, he was inspired by, for example, John Cage, whose philosophical way of thinking had a positive impact on Paik's future experiments with 
music and objects. Exposition of Music - Electronic Television (1963, Wuppertal) was artist's symbolic transfer from music to visual arts, presenting prepared pianos together with prepared TV's. The article presents the exhibition as well as the environment created by Paik, showing the equality, importance and impact of two not so different kinds of art.

\section{Keywords}

Nam June Paik, Fluxus, performance, avant-garde, electronic music 